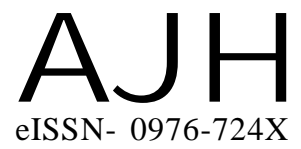

Received : 06.03.2014

Accepted : 30.11 .2014

Members of the Research Forum

Associated Authors:

${ }^{1}$ Depatment of Horticulture, Bihar

Agriculture University, Sabour,

BHAGALPUR (BIHAR) INDIA

Author for correspondence : K.P. SINGH

Krishi Vigyan Kendra, ARWAL (BIHAR) INDIA

Email : kpsinghhort@gmail.com
THE ASIAN JOURNAL OF HORTICULTURE

Volume $9 \mid$ Issue 2 |Dec., 2014 | 518-519

Visit us -www.researchjournal.co.in

\title{
Correlation and multiple regression studies in cauliflower (Brassica oleracea var. botrytis L.)
}

\section{K.P. SINGH, ASHISH RANJAN ${ }^{1}$, RAVINDRA KUMAR ${ }^{1}$, B. PATEL ${ }^{1}$ AND JHABBU RAI ${ }^{1}$}

ABSTRACT : The experiment on cauliflower cv. PUSHI was carried out to find out the correlation and multiple regression co-efficients among different characters. Yield was found to be highly significantly and positively correlated with all the ancillary characters viz., curd depth (0.9183), curd diameter (0.9053), weight of curd (0.8991), plant height (0.8897), weight of plant (0.8738) and plant girth (0.6861) the multiple regression co-efficients were found to be non significant due to multi collinearly between the characters. The step wise regression analysis showed that curd depths have highest contribution towards field followed by curd weight, curd diameter and plant height while the lowest contribution was due to plant girth and weight of plant.

KEY WORDS : Correlation, Regression, Cauliflower

HOW TO CITE THIS ARTICLE : Singh, K.P., Ranjan, Ashish, Kumar, Ravindra, Patel, B. and Rai, Jhabbu (2014). Correlation and multiple regression studies in cauliflower (Brassica oleracea var. botrytis L.). Asian J. Hort., 9(2) : 518-519. 